\title{
The Constitutional Court in the Context of Democratization: The Case of South Korea ${ }^{1}$
}

\author{
By Kun Yang
}

Some thirty countries throughout the world have been in democratic transition since the 1970s, according to Samuel P. Huntington. He called this trend of the late twentieth century "The Third Wave of Democratization". ${ }^{2}$ From a legal or institutional perspective, a remarkable aspect of this wave of democratization, not specifically mentioned by him though, is the establishment of constitutional courts in a substantial number of countries in the process of democratization: to name some of them, Greece (1975), Spain (1978), Portugal (1982), Hungary (1989), Russia (1991), South Africa (1994), and South Korea (1988).

The purpose of this paper is to provide an overview of the recent South Korean experience in operating a constitutional court system and to make suggestions for those countries in constitutional transition.

\section{An Overview of the Constitutional Court System}

\section{a) The Background}

Since the establishment of the first republic in 1948, South Korea has experienced many political turns and twists. Syngman Rhee's regime of the First Republic changed into a dictatorship in the 1950s, and the democratic regime of the Second Republic, founded in the wake of the "student revolution" of April 1960, was overthrown by a military coup in 1961. The Third Republic, which was established by General Park Chung-Hee in 1963 after a period of martial law, turned into a full-scale authoritarian system in 1972. This Fourth Republic, often called the Yushin system, lasted until 1979 when Park was assassinated by his right-hand man. After a period of confusion, General Chun Doo-Whan took power and set up the Fifth Republic in 1980. Chun's regime was the most blatant dictator-

This paper is a slightly revised version of the paper with the same title which was presented at the Conference on „Constitutional Change: Hong Kong 1997 and Global Perspective“, on May 31, 1997, at the Hong Kong Convention and Exhibition Centre. The original paper partially drew on the author's previous article, ,Judicial Review and Social Change in the Korean Democratizing Process", 41 American Journal of Comparative Law 1 (1993). 
ship since the founding of the First Republic of Korea. It was only after the massive citizens' protest and the following constitutional reforms of 1987 that Korea began to enter the still on-going process of democratization. Passing through a transitional period of Roh TaeWoo's government, Korea has now been in "the era of civilian democracy" since the inauguration of former President Kim Young-Sam in 1993. After that, Kim Dae-Jung, a legendary long-time dissident, won the presidential election which was held in December 1997. This is the first turnover in South Korea from a popularly elected government of one party to a popularly elected government of a different party. ${ }^{3}$

Throughout fifty years of these political upheavals, Korea has had a judicial review system in one form or another. With each change of government, and the consequent constitutional revision, the judicial review system also changed, varying in type from the European to the American, or mixed. There is probably no other country which has experienced so many changes in its judicial review system within such a relatively short period of time. Despite the continued existence of an institution for judicial review, however, its actual operation was quite disappointing. Particularly, in the fifteen years of the Fourth and the Fifth Republic, the Constitutional Committee, then the institution for judicial review, remained merely a nominal institution that existed only on paper. Not a single case was ever referred to the Constitutional Committee in spite of the existence of many repressive laws infringing on human rights during this period. This unfortunate situation began to change with the implementation of the new democratic Constitution of the Sixth Republic in $1988 .{ }^{4}$

\section{b) The Jurisdiction of the Court ${ }^{5}$}

The current Constitution introduced the constitutional court system of the European type. The old Constitution of the Second Republic (1960-61) set forth the provision establishing the constitutional court, but unfortunately, the court was aborted due to a military coup in 1961. Thus, the current system of the Constitutional Court is the first one ever having been implemented in Korean constitutional history.

Under the current Constitution, the Constitutional Court has jurisdiction

1) to review the constitutionality of laws,

For an overview of the Korean modem history, see Bruce Cummings, Korea's Place in the Sun: A Modem History, New York, London: Norton, 1997.

4

For a brief historical overview of judicial review in South Korea, see Dae-Ky $u$ Yoon, Law and Political Authority in South Korea, Boulder: Westview, 1990, p. $150-199$.

5

For details, see James M. West / Dae-Kyu Yoon, The Constitutional Court of the Republic of Korea: Transforming the Jurisprudence of the Vortex?, 40 The American Journal of Comparative Law 73 (1992). 
2) to decide on impeachment of high officials including the President,

3) to dissolve political parties on account of their unconstitutional purposes or activities,

4) to decide intragovernmental jurisdictional controversies, and

5) to adjudicate "constitutional petitions", which can be said to be the Korean equivalent of the German "Verfassungsbeschwerde".

In regard to the judicial review of the constitutionality of laws, the Constitutional Court's jurisdiction is in principle limited to statutes enacted by the National Assembly, whereas the Supreme Court has the power to make a final review of the constitutionality of administrative decrees, regulations or actions when their constitutionality is at issue in an ordinary trial.

The judicial review of the constitutionality of statutes, which is the core of the Constitutional Court's jurisdiction, is initiated upon the request of the trial court with original jurisdiction over the case. The request may be made by the court on its own or at the request of the parties involved. If the court decides that the constitutionality of a particular statute is doubtful, and the final judgment in the case will be predicated on an application of the statute, it is required to refer the question to the Constitutional Court. When denied the referral of a constitutional question by the trial court, a party may petition directly to the Constitutional Court through the procedure of Constitutional Petitions. In either case, the Constitutional Court's jurisdiction over the judicial review can be invoked only when a constitutional question is formulated as a concrete case, which is often called a "concrete judicial review".

The most salient feature of the current Constitutional Court system is found in the recognition of the power of the Court to adjudicate Constitutional Petitions. This procedure enables citizens whose fundamental rights have been allegedly infringed upon by the exercise or non-exercise of public power to petition for relief to the Constitutional Court. The procedure has been invoked most of ten when ordinary judicial remedy is unavailable.

\section{c) The Composition of the Court}

The Constitutional Court is composed of nine presidentially appointed Justices. Three Justices are selected at the President's discretion, three are nominated by the Chief Justice of the Supreme Court, and three by the National Assembly.

The head of the Constitutional Court is designated by the President from the Justices with the consent of the National Assembly. All nominees to the Court must be qualified as judges by virtue of passage of the state judicial examination. The Justices are to sit for six years and may be reappointed. For the Court to make a decision of the unconstitutionality 
of a law, of impeachment, of dissolution of a political party, or of granting a constitutional petition, the concurrence of at least six of the nine Justices is required, while a simple majority is sufficient in cases on intragovernmental jurisdictional disputes.

\section{The Actual Operation of Constitutional Adjudication}

When the Constitutional Court opened in September 1988, many jurists were skeptical about the future of this newly born institution. Contrary to the forecasts of many, the Court plays a significant role in the governmental process.

Above all, the institution has become a very busy place. According to statistics as of December $31,1997,^{6}$ there had been a total of 3,780 cases brought before the Court, of which 341 cases were for review of constitutionality of statutes at the request of ordinary courts, 5 cases for review of jurisdictional dispute between state organs, and the remaining 3,434 cases for review of Constitutional Petitions. Today the number of filings remains high. In the year 1997, the total number of cases brought before the Court was 538: 15 referred to the Constitutional Court by ordinary courts for review of constitutionality of statutes, and 523 for review of Constitutional Petitions.

The resulting dispositions of cases also deserve attention. As of December 31, 1997, the Court rendered decisions on the constitutionality of statutes in 226 cases, in which it held laws "unconstitutional" in 40, "inconsistent with the Constitution" in 16, "unconstitutional in part" in 4, and "unconstitutional according to specific interpretation" in 3. The percentage of rulings of unconstitutionality of statutes amounts to $27.9 \%$ altogether in their various forms of judgment. Further, the Court granted petitions relating to the Constitution in 149 cases altogether in their various forms of decision, out of 1,237 cases in which final judgments were reached on the merits. This amounts to $12 \%$. What follows are brief summaries of some major cases of jurisprudential or practical importance which may afford a glimpse of the general trend or characteristics of the Court's rulings.

\section{a) National Security Act Cases}

One of the most controversial legal issues in the Korean democratization process concerned the National Security Act. The purpose of this Act is allegedly to guard against threats from North Korea, but it was not unusual in the past for people just protesting against the government to be punished under this Act. Particularly, Article 7 of the Act, which pro-

6

The source of the following statistics is Honbop Jaepanso Kongbo (Official Bulletin of the Constitutional Court) No. 25 (1998) 30. 
hibited "praising, encouraging, or siding with the activities" of an "anti-State organization", served a a n important legal mechanism for suppressing freedom of political expression.

Challengers to the Act brought the question of its unconstitutionality before the Constitutional Court. In an 8 to 1 decision rendered in April 1990, the Court upheld the constitutionality of the Act "on condition of proper interpretation." The majority opinion of the Court, while acknowledging constitutional deficiencies in the ambiguity of the Act, held that "(Article 7) shall be applied only to such cases that the act in question threatens the existence and security of the state, or injures the basic order of a liberal democracy, and therefore the provision is not violative of the Constitution according to such interpretation". 7

In May 1991, subsequent to the above ruling, the National Security Act underwent a minor amendment which partially reflected the Constitutional Court's judgment. Nevertheless, even the revised Act was challenged again. In October 1996, the Constitutional Court, again in a 8 to 1 ruling, found the revised Act constitutional. This time, the majority opinion of the Court did not attach any condition to its judgment of the constitutionality of the law. ${ }^{8}$

\section{b) Periodicals Act Case}

Under the Periodicals Act, "registration" with the Minister of Information is required as a precondition for publishing periodicals. Moreover, to register a daily or a weekly, a publisher is required to be equipped with certain specified printing facilities. In specifying the requirements, an administrative order, enacted pursuant to the Act, prescribed an ownership of facilities by a publisher.

In June 1992, the Constitutional Court ruled on a constitutional challenge to the regulations of the Act. Regarding the requirement of registration, the Court upheld the Act, distinguishing registration from licensing or censorship. As to the printing facilities requirement, however, the Court found it unconstitutional to require "ownership" of specific facilities, stating that the facilities were of a type that might be leased or used on a contract basis. A sole dissenting Justice was of the opinion that the mandatory registration per se was unconstitutional. $^{9}$

Constitutional Court Judgement of April 2, 1990, 89 Heonka 113.

8 Constitutional Court Judgement of October 4, 1996, 95 Heonka 2.

Constitutional Court Judgement of June 26, 1992, 90 Heonka 23. 


\section{c) Motion Pictures Censorship Case}

The Motion Pictures Act required submission of all motion pictures for "examination" by the Public Performance Ethics Commission prior to their public exhibition. When the Commission found a film falling under specified standards, it was to prohibit the showing of the film. The Commission, composed of members appointed by the government, was also empowered to grant a permit of exhibition on condition of deleting portions of a motion picture in question.

In a unanimous decision rendered in October 1996, the Constitutional Court struck down the movie censorship which had been maintained for over fifty years. The Court noted, however, that the rating of movies as practiced in the United States would not be contrary to the Constitution in view of the impact of films on youth. ${ }^{10}$

\section{d) Presidential Election Law Case}

The Presidential Election Law, enacted in 1987 and revised in 1992, stipulated strict regulations of campaign activities. Among others, ordinary citizens were prohibited from being engaged in campaign activities, with the exception of family members of candidates or the very limited number of registered campaigners selected by the political parties or candidates.

In a 7 to 2 decision in 1994, the Constitutional Court invalidated the regulatory provision, holding that the regulation excessively restricted freedom of political expression. The Court went on to state that, except a certain scope of public employees and those without voting rights, citizens' campaign activities should be guaranteed as long as they were not in the position of injuring the electoral fairness. ${ }^{11}$

\section{e) Special Act on the May 18th Democratization Movement Case}

In December 1995, a special law was enacted to deal with the problem of limitation constraints on punishing former presidents Chun and Roh and their clique. The law, entitled Special Act on the May 18th Democratization Movement (often called the "5.18 Special Act"), provides that the statute of limitations is suspended from running with respect to offenses connected with the military mutiny of December 1979 and the Kwangju massacre

10 Constitutional Court Judgement of October 4, 1996, 93 Heonka 13, 91 Heonka 10.

11 Constitutional Judgement of July 29, 1994, 93 Heonka 4, 6. 
of May 1980 "during the period in which there existed a cause preventing the nation from exercising its prosecutorial powers." Further, the Special Act defines such period of suspension as "from the date on which the criminal conduct in question was completed until February 24, 1993." The latter date is when President Kim Young-Sam was inaugurated. In February 16, 1996, the Constitutional Court rendered a ruling on the constitutional issues involved in the Special Act. Four Justices of the Court found the Special Act constitutional. According to their opinion, the interests of the accused in relying on the statute of limitations are not constitutionally guaranteed, but just of a statutory dimension, and in this case, the public interest in punishing the of fenders who committed "crimes destructive of constitutional order" outweigh the interests of accused persons or the interests in preserving legal stability. The other five Justices of the Court, however, were of the opinion that the Special Act was unconstitutional. They argued that the enactment to prosecute persons for whom the statute of limitations already expired was equal in its effect to retroactive penal legislation which is expressly prohibited by the Constitution. ${ }^{12}$ Though outnumbered by one vote, the minority opinion supportive of the constitutionality of the Special Act prevailed, because under the Constitutional provision, as mentioned in the foregoing, a majority of at least six of the nine Justices of the Court is required for a judgment of unconstitutionality of a law. ${ }^{13}$

\section{Causes and Limits of Judicial Activism}

\section{a) Factors Contributing to the Activism}

Compared to past experiences in judicial review, the above results are indeed remarkable despite criticisms from the more progressive perspective. Then, what has brought about such notable changes? First of all, it goes without saying that the altered political environment through transition to democracy made the basis for activation of constitutional adjudication. But for the democratic reforms of 1987, the current active operation of the Constitutional Court could not even be conceived of.

Beyond a more liberated political climate as a precondition, what factors have contributed to the facilitation of the constitutional adjudication? To find an answer to this question, attention need to be focused on the changes in attitudes of three major actors involved in constitutional litigation: citizens, lawyers, and judges. 
First, as far as the increase in the number of cases referred to the Constitutional Court is concerned, it is surely due to people's heightened consciousness of rights in general, and especially their increasing expectations of the newly established constitutional court system. Perhaps it is also the track record of the Constitutional Court, that is, the public now realize that their petitions have a chance of winning. In connection with this, an institutional factor merits attention. The new "constitutional petition" jurisdiction of the Constitutional Court must be considered an epoch-making development for constitutional justice in that a direct procedural route has been created for a citizen to mount a challenge to the constitutionality of an exercise or non-exercise of public power.

Next, it should be emphasized that activist lawyers have been playing an important role. A group of political lawyers, often called "human rights lawyers", have been active since the authoritarian rule of 1970s. They have done pro bono work on behalf of political of fenders, and as core members of the Human Rights Committee of the Korean Bar Association, have taken the lead in a variety of activities for the protection of human rights. After the constitutional reforms of 1987, they formed an organization named "Lawyers for Democratic Society", which became the center for public interest activities including constitutional litigation. $^{14}$

Finally, most important, the existence of activist judges must be indicated as a crucial condition. On the selection of Justices of the Korean Constitutional Court, the presidential influence is decisive. Throughout the first and second terms of the Court, only one or two out of nine of the Court Justices were selected from nominees recommended by opposition parties. Considering that concurrence of at least six Justices is required to decide the unconstitutionality of legislation or to grant Constitutional Petitions, the achievements of the Court to date show how active the Justices have been, even though they have revealed cautious attitudes in several cases of highly political significance.The question is, then, what has caused such changes in judicial attitudes? An institutional factor on a basic level seems to have a direct bearing on such unexpected changes. It is the installation of a special organ for constitutional adjudication, separated from ordinary courts. A further inquiry into this matter will follow later.

\section{b) "Limited Activism"}

In spite of the unprecedented boom in constitutional adjudication, however, the Constitutional Court has shown substantial reservation with regard to cases having highly political 
implications. The cases involving the National Security Act or the 5.18 Special Act are good examples to illustrate the point.

In the National Security Act case of 1990, the Court made use of the jurisprudential technique such as the judgment of "limited constitutionality" of a law. This method of interpretation presupposes an acknowledgment that a law in question has some constitutional deficiency. But the main thrust of this form of decision lies in the judgment that the law under review is basically constitutional, despite an attached reservation that the law in question is not against the Constitution "on condition of proper interpretation."

This form of constitutional judgment is not unique to the Korean Constitutional Court. The problem is, however, that it has been abused in many instances. Too narrow an interpretation of a statute often happens. More problematic is that the Court did not take into consideration how the law in question actually had been interpreted and applied by law enforcement authorities or ordinary courts.

Meanwhile, in the 5.18 Special Act case, the self-restrained attitude of the Constitutional Court takes on another form of judgment: a "4 to 5 decision" in which four Justices' opinion supportive of the constitutionality of statute prevails in effect over the opinion of five Justices against the constitutionality of the law. By what process nine Justices of the Court came to reach such a delicate decision is unknown. Anyway, this form of judgment seems to imply that, on the one hand, the law in question is virtually unconstitutional, but, on the other, the formal declaration of the unconstitutionality of the law is inappropriate in view of political reality or from the perspective of legal stability.

Evaluations differ on the "limited activism" of the Constitutional Court. Those unsatisfied with the slow progress of democratization strongly criticize the judicial restraint in cases of political significance, while others understand it as inevitable for the sake of preserving the Court itself.

\section{The European or American Type of Judicial Review?: A Proposition from the Korean Experience}

What is the institutional factor of fundamental importance, if any, for the successful operation of constitutional adjudication system? In view of the Korean experience, the choice between two types of constitutional adjudication seems to bear some relation to this question: the European type of constitutional review by special court or American type of judicial review by ordinary courts? 
On this issue, comparative legal scholars have already expressed preferences for the European constitutional court system. Mauro Cappelletti may be cited as representative. Among various reasons for his support of the European "centralized system" in his own term, the most notable is his indication of "the mentality required for an effective control over the constitutionality of legislation." According to him, while "the task of fulfilling the constitution often demands a higher sense of discretion than the task of interpreting ordinary statutes," the traditional courts of most civil law countries seem "psychologically incapable of the value-oriented, quasi-political functions involved in judicial review". ${ }^{15}$ An opinion of similar tone is also found in the work of J.H. Merryman. ${ }^{16}$ Even outside of European civil law countries, the argument that the European type of constitutional adjudication is more conducive to judicial activism than the American type of judicial review seems to be valid. Although Japan is the most advanced country in Asia, her experience in judicial review modeled after the American type has not been encouraging. The Japanese Supreme Court held laws unconstitutional in very few cases. ${ }^{17}$

In contrast, the recent Korean experience in the constitutional court system may be cited as a new evidence for the proposition that the European centralized system has the edge over the American decentralized system. Korea once adopted a judicial review system of the American type during the period of the Third Republic (1963-72). In the nine years of its operation, however, the Supreme Court held a law unconstitutional in only one instance. Of course, it is hardly denied that the political climate after the 1987 reforms has been more favorable to judicial review than in the period of the Third Republic. Even so, shifting to the European constitutional court system seems to be a significant institutional factor contributing to the recent activism in constitutional adjudication.

If so, what aspect of the constitutional court system has made all the difference? Once the Constitutional Court was established, the prime concern of Justices of the Court seemed to be raising and maintaining the prestige of the Court as one of the highest state organ. For this purpose, they needed to show an active posture in striking down problematic laws which had been criticized and challenged as unconstitutional, subject of course to political circumstances. Rather cynical as it may sound, the establishment of a special organ for judicial review has created an atmosphere of what can be called an "institutional egoism",

M. Cappelletti, Judicial Review in the Contemporary World, Indianapolis: The Bobbs-Merril, 1971, p. 62, 3.

J. H. Merryman, The Civil Law Tradition, Stanford: Stanford University Press, 2nd ed., 1985, p. 139.

17

Until 1985 the Japanese Supreme Court had found only three laws to be unconstitutional. Several times since 1985 the court has ruled against legislative apportionment plans on "one person-one vote" grounds. See J. Sanders, Courts, Law \& Politics in Comparative Perspective, New Heaven: Yale University, 1996, p. 327. 
thus making the Court less hesitant in invalidating unconstitutional laws. This job has been by no means easy for the Court. If the Court passes a certain invisible line, a political counteraction my result. An incident in 1991 is suggestive in this regard. As the Court handed down not infrequently decisions of unconstitutionality, the ruling party revealed an intention to curtail the jurisdiction of the Court by revision of the Constitutional Court Act. Faced with strong objections of public opinion, the party withdrew this plan.

Anyway, it is thought that caring about "institutional interests" by Justices is not peculiar to the Korean Court. In the American type of judicial review, given that the main task for ordinary courts is to adjudicate in ordinary lawsuits, constitutional questions may be regarded as peripheral or burdensome. In contrast, a constitutional court concerns itself solely with constitutional issues. If it keeps a passive and self-restrained attitude in dealing with constitutional issues, a question will be raised about the raison d'être of the institution. A story behind the creation of the Korean Constitutional Court illustrates this point well. At the time of the enactment of the current Constitution, most of the then Justices of the Supreme Court disfavored the proposed expansion of their jurisdiction to include constitutional adjudication. They wanted to be relieved of heavy political burden.

\section{Concluding Remarks}

The history of democratization is not unidirectional. As Huntington pointed out, the first two waves of democratization in the past were followed by reverse waves. ${ }^{18}$ Today South Korea is taking the third opportunity for democratization, after going through failures in 1961 and 1980. Most South Korean people believe that they are now in the process of democratic consolidation. In this process, the role of the Constitutional Court has been remarkable despite some criticisms. The Court has become an important institutional arbiter of the pace and extent of the transition to democracy. It is not uncommon now that policy makers take into consideration constitutional matters in their decision-making, not to mention that general citizens have resort to constitutional litigation seeking remedies for inf ringement on their constitutional rights. This is quite a new phenomenon.

The constitutional court in a context of democratization is apt to be in a dilemma. If the court goes ahead too far without taking account of the political environment surrounding it, the democratization process might be plunged in confusion. On the other hand, if the court merely follows the footsteps of political decision-makers, a question will be raised about what the court is for. The only way out of this quandary is to look to the courage and wisdom of justices of the constitutional court as "Hüter der Verfassung" (guardian of the Constitution).

18

Huntington, supra p. 1521. 


\title{
The Constitutional Court in the Context of Democratization: The Case of South Korea
}

\author{
By Kun Yang
}

The Constitutional Court of South Korea was established in 1988. Since then, the Court has become an important institutional arbiter of the pace and extent of the transition to democracy. This paper aims to provide an overview of recent South Korean experience in operating a constitutional court system from a socio-legal perspective. Following the introductory description of background, jurisdiction and composition of the Constitutional Court, some major cases are examined along with the statistics of disposition of cases.

Further, the general trend and character of Korean constitutional adjudication are discussed. Attention is focussed on the conditions and limits of judicial activism. The final section inquires into an institutional factor for the successful operation of a constitutional adjudication system. It is argued in particular that the European type of constitutional court system is preferable to the American judicial review system.

\section{The Southern African Development Community (SADC) after Apartheid: New Goals, old Problems}

\section{By Peter Meyns}

Originally founded to reduce the dependence of its member countries on Apartheid South Africa, the South African Development Coordination Conference (SADCC) redefined and renamed itself as the end of Apartheid drew close. This contribution looks at the Southern African Development Community (SADC) in the 1990s focussing in particular on institutional aspects. With regard to the existence of competing regional organizations in southern Africa it is argued that SADC is today the preferred institution having gained a decisive advantage over the Common Market for Eastern and Southern Africa (COMESA) when the new democratic government in the Republic of South Africa decided to become a member. Progress towards the implementation of the new integration agenda is still slow, however. Here, it is suggested that the decentralised sectoral structure which SADC inherited from SADCC might now prove to be a hindrance to strengthening the regional decision-making level and, in the process, progress towards the free trade zone proclaimed in the 1996 trade protocol. The reluctance of member states to relinquish their national sovereignty in favour of the common regional course is also visible in the initial experiences of the recently established SADC "Organ on Politics, Defence and Security". It is concluded, therefore, that, if SADC is to advance to a higher level of integration, concrete measures aimed at achieving the "development integration" envisaged will be needed rather than high-flown political proclamations. 